\title{
Effects of Pretreatments on the Production of Bioethanol from Manihot esculenta Crantz Peels Using Zymomonas mobilis
}

\section{Deke Victoria Adegunloye and Janet Olawumi Olowe*}

Department of Microbiology, School of Life Sciences, Federal University of

Technology Akure, Nigeria

*Corresponding Author: Janet Olawumi Olowe, Department of Microbiology,

School of Life Sciences, Federal University of Technology Akure, Nigeria.
Received: September 01, 2021

Published: October 25, 2021

(C) All rights are reserved by Deke Victoria

Adegunloye and Janet Olawumi Olowe.

\begin{abstract}
Waste management is a global issue which has become increasingly serious with population and economic growth, particularly in Nigeria. Bioethanol is a suitable substitute to hydrocarbon as it is produced by fermenting carbohydrate biomass derived from plants. This research investigation, the use of cassava peels serves as the main carbon source for production of bioethanol. Bioethanol production from the peels of cassava was examined using co-culture of Aspergillus niger and Zymomonas mobilis through simultaneous saccharification and fermentation process. $0.1 \mathrm{M}$ sulphuric acid and sodium hydroxide was used for substrate pretreatment. Aspergillus niger and Zymomonas mobilis were added to ferment the peels at $28^{\circ} \mathrm{C}$ for 5 days during which the total bacterial and fungal count, mineral composition, cellulose content, reducing sugar, $\mathrm{pH}$, temperature and the quantity of bioethanol produced were determined. The bacterial count $\left(3.58 \times 10^{3}\right)$, fungal count ( $\left.2.81 \times 10^{3}\right)$, mineral composition $(15.64 \mathrm{mg} / 100 \mathrm{~g})$, cellulose content $(66.08 \%$ and $69.29 \%)$, reducing sugar (6.98 \pm 0.01 and $8.98 \pm 0.00 \mathrm{~g} / \mathrm{l}), \mathrm{pH}(7.67)$, temperature was at $36^{\circ} \mathrm{C}$ at the initial stage of fermentation and later remain static at $28^{\circ} \mathrm{C}$ till $5^{\text {th }}$ day of fermentation, the total quantity of bioethanol yield obtained was $(17.08 \mathrm{~g} / \mathrm{ml})$ after the $5^{\text {th }}$ day of fermentation. Fermented hydrolysate was distillated at $78^{\circ} \mathrm{C}$. Therefore, Aspergillus niger and Zymomonas mobilis are proven effective for saccharification and fermentation of cassava peels for bioethanol production as an alternative fuel and energy source.
\end{abstract}

Keywords: Bioethanol; Cassava Peels; Pretreatment; Fermentation

\section{Introduction}

Biofuels are expected to reduce dependence on imported petroleum with associated political and economic liability, diminish greenhouse gas emissions and other pollutants, and invigorate the economy by increasing demand and prices for agricultural products [1]. There is an increasing demand for bio-ethanol as alternative source of energy and Nigeria currently depends on the importation of ethanol to meet its local demand.
Cassava is a very cheap source of carbohydrate and is the main carbohydrate source in the diet of the teeming population of the third world countries where it is largely grown. Banjoko., et al. [2] posited that cassava is a supplementary staple food of more than 200 million Africans aside from its uses as livestock feed particularly for monogastrics animals. Cassava is the most widely distributed major food crop with a high content of cyanogenic glycosides. It is also known as Manioc (Manihot esculenta), yuca tapioca, or guacamate. Other foods such as sweet potatoes, yams, maize, mil-

Citation: Deke Victoria Adegunloye and Janet Olawumi Olowe. "Effects of Pretreatments on the Production of Bioethanol from Manihot esculenta Crantz Peels Using Zymomonas mobilis". Acta Scientific Microbiology 4.11 (2021): 66-74. 
let, bamboo sugarcane, peas, beans, as well as kernel of almond, lemon, lime, apple, pear, cheery, apricot, prune and plum contains cyanide. Cassava contributes immensely to human nutrition and livelihood of the world [3] as varieties of products such as starch, garri, cassava flour, and fufu are commonly processed from cassava tubers. During the processing of cassava tubers into these essential products, an enormous quantity of cassava peels (about 30\% of processed cassava tubers) are generated as waste [4] and only an insignificant proportion is usually fed to livestock such as goats. The remaining, usually heaps are thrown along roadsides in places where cultivation and processing of cassava tubers is a common livelihood activity. The peels and other wastes such as chaffs are being considered as an inconvenience rather than a potential resource in West Africa [5]. The potential of these peels to be used in the production of other products such as biogas, mushroom and improved animal feed has also been established by previous scholars [6-10]. However, most of the cassava processors and farmers are neither aware of the technologies that can be used to add value to cassava peels neither were they knowledgeable about the procedure of these different technologies. This informs why most cassava processors still throw away the peels instead of either converting it to usable forms or selling the peels as an additional source of income. Aside from not getting additional source of income from adding value to cassava peels, the environmental nuisance constituted by cassava peels on dumping sites "Akitan" cannot be overlooked.

Generally, pretreatment improves the predisposition of polysaccharides to hydrolysis of cassava peels which influences the structural and compositional constituents of Cassava peels [11]. A reduced cost of pretreatment would have a noteworthy bearing on the inclusive cost of ethanol production. However, a major impediment in bioethanol production from cassava peels is the removal of bioactive fibre component which is exceedingly impervious to solubilization and is also a key inhibitor for hydrolysis of cellulose and hemicellulose in the molecular structure of cassava [11]. Some of the major factors are the recalcitrance of the cassava plant cell wall due to essential fundamental complexity of fibre-related compounds [12]. Precious little studies have been conducted on the efficacy of pretreatments on the synthesis of bioethanol from cassava peels utilizing facultative anaerobes Zymomonas mobilis. Therefore, the effects of pretreatments on the production of bioethanol from Manihot esculenta Crantz peels using Zymomonas mobilis. The aim of this study is to ascertain the effect of pretreatments on the production of bioethanol from cassava peels using Aspergillus niger and Zymomonas mobilis.

\section{Materials and Methods}

\section{Samples collection}

Cassava peels (CP) and rotten oranges were collected from a local garri processing industry and local vendors located at Shagari village and Southgate, Akure, Ondo State. The samples were aseptically collected into a polythene bag and taken to the laboratory for further analyses. The cassava peels were washed thoroughly with distilled water to eliminate adhering soil and dust. The peels were sun-dried and then grinded into powdered form. The grinded powder was then sieved through muslin cloth to standardize the particle range of $1 \mathrm{~mm}$. The samples were kept in a tightly close container at room temperature.

Biochemical characterization of Aspergillus niger and $\mathrm{Zy}$ momonas mobilis from cassava peels and rotten oranges

Aspergillus niger was isolated from the cassava peels while $Z y$ momonas mobilis was isolated from rotten sweet oranges using standard microbiological methods as described by Hemraj., et al. [13]. The cultures were characterized and identified using morphological and biochemical methods described by Fawole and Oso [14].

\section{Bioethanol production from Manihot esculenta peels}

The pretreatment phase of the bioethanol production was conducted utilizing the protocol of Saha and Cotta [15] with trivial alterations. $20 \mathrm{~g}$ each of the cassava peels was weighed and poured in a $500 \mathrm{ml}$ conical flask, then distilled water, and $0.1 \mathrm{M}$ of sulphuric acid $\left(\mathrm{H}_{2} \mathrm{SO}_{4}\right)$ and sodium hydroxide $(\mathrm{NaOH})$ were added separately to each conical flasks. Sterile distilled water was added to make up to $200 \mathrm{ml}$, they were autoclaved at $121^{\circ} \mathrm{C}$ for 15 minutes and were allowed to cool down and filtered using a sterile muslin cloth. The $\mathrm{pH}$ of the medium was adjusted to 6.0 using $\mathrm{H}_{2} \mathrm{SO}_{4}$ normal and $\mathrm{NaOH}$. The residual samples were washed with sterile distilled water to obtain a neutral $\mathrm{pH}$ for all treatment. The residual samples were oven-dried at $90^{\circ} \mathrm{C}$ overnight and the hydrolysates obtained were subjected to further analyses. The fermentation of the cassava peel hydrolysates was conducted with concurrent saccharification and fermentation process (SSF), as described by [16]. 
The hydrolyzed samples were autoclaved at $121^{\circ} \mathrm{C}$ for 15 minutes and allowed to cool at room temperature. Co-cultures of Aspergillus niger and Zymomonas mobilis was aseptically inoculated into each flasks containing the hydrolyzed samples while the untreated cassava peels serve as control. The flasks were incubated at room temperature $\left(28^{\circ} \mathrm{C}\right)$ for five days. The flasks were shaken at interval for homogenicity with even distribution of the organisms in the hydrolyzed samples achieved. The fermented liquid was transferred into a round bottom flask and placed on a heating mantle fixed to a distillation column embedded to a running tap water. Another flask was fixed to the other end of d column to extract the distillate at $78^{\circ} \mathrm{C}$ which is the standard temperature for the production of ethanol as depicted by Oyeleke., et al. [17]. pH meter (pH meter (pH 7110) (Inolab, Xylem Analytics, Bellingham Stanley, UK) was first calibrated and inserted into each filtrate. The readings were recorded according to the method used by Ademiluyi., et al. [18].

\section{Determination of quantity of bioethanol produced}

The distillates collected from the fermented broth were measured using a measuring cylinder and expressed as quantity of ethanol produced in $\mathrm{g} / \mathrm{l}$ by multiplying the volume of the distillate by the density of ethanol $(0.8033 \mathrm{~g} / \mathrm{ml})$ [19].

\section{Determination of reducing sugar produced}

The reducing sugar was determined by titrimetric methods. Thirty (30) $\mathrm{ml}$ of fermentation broth was weighed into the burette. Ten ml of mixed Fehling's solution was pipetted into a conical flask and 4 drops of $1 \%$ methylene blue indicator was added. The solution was heated and while boiling, the broth in the burette was titrated against the solution in the conical flask until the colour disappeared as described by Srichuwong and Jane [20].

The reducing sugar was calculated as follows:

$\%$ Reducing sugar $=47.5 \times 300 / \mathrm{T} \times \mathrm{W}$

$\mathrm{T}=$ Titre value

W = Weight of the peel sample (in grams).

\section{Determination of temperature during fermentation}

The temperature was obtained using a calibrated thermometer. The thermometer was inserted into the fermented broth and readings were then taken.

\section{Results and Discussion}

The effects of pretreatment on bioethanol production from Manihot esculenta Crantz peels using Zymomonas mobilis was assessed in this study. Findings from this research experiment (Table 1) have found Bacillus cereus and Bacillus anthracis to be evidently prevalent in Cassava peels (Manihot esculenta). This is attributed to the nature of the environment from which the samples were collected which can be proficient consortium for other microorganisms to survive. Bacillus are heterogenous and they are very versatile in their adaptability to the environment. In fact, in a related research, displayed the activity of bacillus in cassava to be 17.0 units $/ \mathrm{ml}$ at pH 4.0 which is acidic [21]. Consequent to this, can pose unheard biohazards to ruminants as well as Zoonotic impression towards man. These impressions are vastly occurring as gastrointestinal symptoms such as stomach pain, nausea, diarrhea etc and in worst cases, death. The presence of Bacillus anthracis could cause food poisoning and blood clotting to animals during consumption of the peels thereby leading to the death of the animal.

Table 2 shows the morphological and microscopy characterization of the fungi isolated from the peels of cassava which shows that Aspergillus flavus and Aspergillus niger were found present in the peels. They are ubiquitous in nature and for some time, have become an increasing cause of life threatening opportunistic diseases for animals during consumption of the peels [22]. The reason for the presence of Aspergillus species in Manihot esculenta peels in this study could be attributed to fungi being a major mycoflora of various agricultural commodities [23,24].

Table 3 shows the morphological and biochemical characteristics of microbial species isolated from rotten orange shows that the organisms are anaerobic short rod, gram negative, catalase positive, non-motile and ferment glucose and sucrose with evolution of gas. Hence, Zymomonas mobilis was pertinent for the fermentation of cassava peel in this study. Findings were compared with Bergey's manual of determinative bacteriology who stated that $Z y$ momonas mobilis are anaerobic gram negative rods with single polar flagellum that ferments fructose, sucrose and glucose with evolution of carbon dioxide. The result also conforms with the work of Rabah., et al. [25] that reported the isolation of Zymomonas mobilis from rotten sweet orange and stated that the organism can thrive 


\begin{tabular}{|c|c|c|c|c|c|c|c|c|c|c|c|c|c|c|c|c|c|c|}
\hline $\begin{array}{l}\frac{\Xi}{\pi} \\
\frac{\pi}{\omega} \\
\bar{\Xi}\end{array}$ & 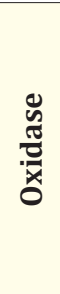 & 营 & $\tilde{w}^{N}$ & 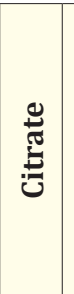 & 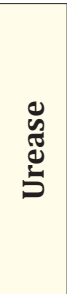 & $\begin{array}{l}\frac{0}{0} \\
\frac{0}{g}\end{array}$ & 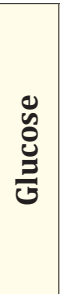 & $\begin{array}{l}\ddot{D} \\
\stackrel{0}{0} \\
\overline{:}\end{array}$ & 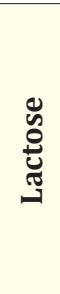 & 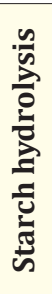 & 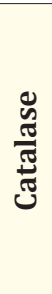 & $\begin{array}{l}\overline{:} \\
\stackrel{\bar{Z}}{\bar{\Xi}} \\
\sum\end{array}$ & 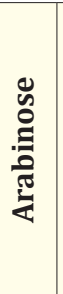 & $\frac{\ddot{\partial}}{\grave{\lambda}}$ & 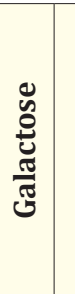 & $\stackrel{n}{\Sigma}$ & $\xi$ & 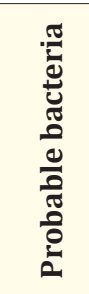 \\
\hline वे & . & + & ' & + & ' & ' & + & + & + & + & + & & & ' & ' & + & ' & 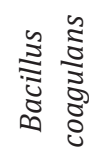 \\
\hline वृ & ' & + & ' & ' & ' & ' & + & + & ' & + & ' & & & ' & ' & ' & ' & 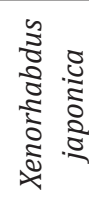 \\
\hline वृ & ' & ' & ' & + & ' & ' & + & ' & + & + & ' & & & ' & ' & ' & ' & 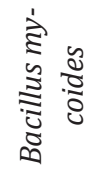 \\
\hline $\begin{array}{l}\overline{0} \\
\propto 2\end{array}$ & ' & ' & ' & ' & ' & ' & + & + & ' & + & + & ' & ' & ' & ' & ' & ' & 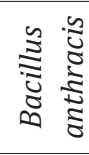 \\
\hline $\begin{array}{l}\bar{a} \\
\approx\end{array}$ & ' & ' & ' & ' & ' & ' & + & ' & + & + & + & ' & ' & ' & ' & i & ' & 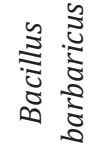 \\
\hline $\begin{array}{l}\overline{0} \\
\propto 2\end{array}$ & ' & ' & ' & ' & ' & ' & + & ' & + & + & + & ' & & ' & ' & ' & ' & 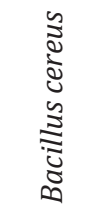 \\
\hline
\end{tabular}

Table 1: Biochemical characterization of the bacterial isolates from Manihot esculenta peel.

Keys: - = negative to the test, $+=$ positive to the test, $\mathrm{MR}=$ methyl red, VP = Voges proskauer, $\mathrm{H}_{2} \mathrm{~S}=$ Hydrogen Sulphide gas production.

\begin{tabular}{|l|c|}
\hline Morphological and microscopy characterization & Fungal isolates \\
\hline $\begin{array}{l}\text { Colonies are white to cream, smooth, glabrous, pseudo-hyphae are formed with large globose to ellipsoi- } \\
\text { dal cells with multilateral budding. }\end{array}$ & Saccharomyces cerevisae \\
\hline $\begin{array}{l}\text { Mycelium growing fast, with black conidia, the reverse of the plate is creamy. } \\
\text { Conidiophores is smooth, black, long and coarse }\end{array}$ & Aspergillus niger \\
\hline Yellowish green colony, present of metular, biseration, sclerotia, smooth surface & Aspergillus flavus \\
\hline $\begin{array}{l}\text { Rapidly growing, consist of green dense form of conidiophores on Potato Dextrose Agar. Conidiophores } \\
\text { are hyaline and rough walled. Phialides are flask-shaped, consisting of a cylindrical basal part and a } \\
\text { distinct neck. Conidia are cylindrically arranged in chain }\end{array}$ & Penicillum notatum \\
\hline $\begin{array}{l}\text { Dark colony colour, rough surface, no sclerotia, brown-green conidia with velvety surface. Conidio- } \\
\text { phores irregularly branched, consisting of short stripes. Conidia are cylindrical an smooth walled }\end{array}$ & Penicillum digitatum \\
\hline
\end{tabular}

Table 2: Morphological and Microscopy Characterization of Fungal Isolates from Manihot esculenta peel. 
in sweet mediums because they love sugar and receive available juices that they utilize as their growth factor.

\begin{tabular}{|l|c|}
\hline Isolated organism/tests & Results \\
\hline Gram reaction & - \\
\hline Motility & - \\
\hline Catalase & + \\
\hline Glucose & + \\
\hline Sucrose & + \\
\hline Lactose & - \\
\hline Maltose & - \\
\hline Fructose & - \\
\hline Urease & - \\
\hline Oxidase & - \\
\hline Citrate & - \\
\hline Indole & - \\
\hline Starch hydrolysis & Zymomonas mobilis \\
\hline Arabinose & - \\
\hline Organism & \\
\hline
\end{tabular}

Table 3: Morphological and biochemical characterization of Zymomonas mobilis from rotten orange (Citrus aurantium).

Keys: +: fermentation/positive; -: no fermentation/negative.

The result in Table 4 showed the percentage content of carbohydrate in Manihot esculenta is higher with $67.84 \pm 0.44 \%$. The carbohydrate content almost conforms to $72.50 \pm 0.02 \%$ according to the findings of Okpako., et al. [26] for fermented cassava peels. Lower than values of $193.1 \%$ carbohydrate yield reported by Adamafio., et al. [27] for the treatment of groundnut shell with potash. They also stated that treatment improve biodegradability of lignocellulosic biomass with increased amount of carbohydrate. This generally shows that Manihot esculenta peels are rich in sugar, which is a serious source of vitality in the animal feed stuff.

The result of the mineral composition (Table 5) showed that the magnesium content of Manihot esculenta was $15.64 \mathrm{mg} / 100 \mathrm{~g}$. Val-

\begin{tabular}{|l|c|}
\hline Parameters & Dry Manihot esculenta (\%) \\
\hline Moisture & $11.33 \pm 0.15$ \\
\hline Ash & $2.39 \pm 0.07$ \\
\hline Crude fat & $1.39 \pm 0.09$ \\
\hline Fibre & $11.68 \pm 0.21$ \\
\hline Protein & $5.44 \pm 0.08$ \\
\hline Carbohydrate & $67.84 \pm 0.44$ \\
\hline
\end{tabular}

Table 4: Proximate composition of Manihot esculenta peels.

Each value is a mean \pm standard deviation of three replicates.

ues obtained showed the magnesium content were lower as compared to report by Charles., et al. [28] with values of $30 \mathrm{mg} / 100 \mathrm{~g}$ and $43 \mathrm{mg} / 100 \mathrm{~g}$. Table 6 showed that the compositional property of the un-treated Manihot esculenta peels samples showed a lignin composition of $15.86 \%$, hemicellulose- $21.43 \%$, cellulose- $62.05 \%$. In a related experiment, analysis of the untreated Manihot esculenta peel, recorded hemicellulose composition of $29.81 \%$, cellulose- $3.05 \%$ and lignin- $2.65 \%$ according to Onyelucheya., et al. [29]. Results by other workers obtained cellulose- $5.40 \%$, hemicellulose- $21.65 \%$ and lignin- $4.81 \%$. The differences in the compositional character may be due to Manihot esculenta variety being analyzed, age of Manihot esculenta, as well as duration of storage before analysis.

The moderately high cellulose content i.e. $66.08 \%$ and $69.29 \%$, derived from Manihot esculenta peels was actualized by catabolic effect of $\mathrm{NaOH}$ and $\mathrm{H}_{2} \mathrm{SO}_{4}$ (Table 6 and 7). This claim is supported by Aripin., et al. [30] who experimented on the production of bio-

\begin{tabular}{|l|c|c|}
\hline S/N & Parameters & Manihot esculenta \\
\hline 1 & Magnesium $(\mathrm{Mg})$ & 15.64 \\
\hline 2 & Calcium $(\mathrm{Ca})$ & 8.84 \\
\hline 3 & Iron $(\mathrm{Fe})$ & 0.81 \\
\hline 4 & Zinc $(\mathrm{Zn})$ & 1.15 \\
\hline 5 & Phosphorus $(\mathrm{P})$ & 3.05 \\
\hline
\end{tabular}

Table 5: Mineral composition of Manihot esculenta peels.

\begin{tabular}{|l|c|c|c|c|c|c|}
\hline & & Before & & & After & \\
\hline Biomass & Lignin (\%) & Hemicellulose\% & Cellulose \% & Lignin \% & Hemicellulose \% & Cellulose \% \\
\hline Manihot esculenta & $15.86 \pm 0.15$ & $21.43 \pm 0.10$ & $62.05 \pm 0.27$ & $14.13 \pm 0.11$ & $24.73 \pm 0.15$ & $66.08 \pm 0.04$ \\
\hline
\end{tabular}

Table 6: Fibre contents of Manihot esculenta before and after pretreatment with $\mathrm{NaOH}$.

Each value is a mean \pm standard deviation of three replicates. 
ethanol from cassava peels. They proved that $1 \% \mathrm{NaOH}$ was potent to pretreat Manihot esculenta peels, as $66 \%$ of cellulose content was recovered from Manihot esculenta peels. Table 8 showed the pattern of the reducing sugar during the fermentation period. The reducing sugar in cassava peel showed that the neutralized hydrolysate produced a higher sugar of $6.98 \pm 0.01$ and $8.98 \pm 0.00 \mathrm{~g} / \mathrm{l}$ respectively. This could be due to the utilization of the sugar as carbon source for the growth of the microorganisms. This is in line with the findings made by Yoonan and kongkiattikajorn [31] with their evidence gathered that high reducing sugar were produced from Manihot esculenta peels, $2.64 \%$ to be exact.

\begin{tabular}{|l|c|c|c|c|c|c|}
\hline & & Before & & After & \\
\hline Biomass & Lignin \% & Hemicellulose \% & Cellulose \% & Lignin \% & Hemicellulose \% & Cellulose \% \\
\hline Manihot esculenta & $31.55 \pm 0.02$ & $24.86 \pm 0.03$ & $69.24 \pm 0.10$ & $\begin{array}{c}31.602 \pm \\
0.02\end{array}$ & $24.915 \pm 0.03$ & $69.29 \pm 0.15$ \\
\hline
\end{tabular}

Table 7: Fibre contents of Manihot esculenta before and after pretreatment with $\mathrm{H}_{2} \mathrm{SO}_{4}$.

Each value is a mean \pm standard deviation of three replicates.

\begin{tabular}{|l|c|c|c|c|}
\hline Period & $\mathbf{H}_{2} \mathbf{S O}_{4}$ & $\mathbf{N a O H}$ & Neutral & Control \\
\hline 24 & $2.30^{\mathrm{c}} \pm 0.10$ & $2.00^{\mathrm{b}} \pm 0.00$ & $3.48^{\mathrm{d}} \pm 0.02$ & $1.48^{\mathrm{a}} \pm 0.00$ \\
\hline 48 & $2.46^{\mathrm{c}} \pm 0.00$ & $1.96^{\mathrm{b}} \pm 0.01$ & $3.47^{\mathrm{d}} \pm 0.00$ & $1.48^{\mathrm{a}} \pm 0.00$ \\
\hline 72 & $2.50^{\mathrm{b}} \pm 0.00$ & $1.00^{\mathrm{a}} \pm 0.00$ & $8.99^{\mathrm{d}} \pm 0.01$ & $2.98^{\mathrm{c}} \pm 0.00$ \\
\hline 96 & $2.97^{\mathrm{b}} \pm 0.01$ & $0.98^{\mathrm{a}} \pm 0.00$ & $8.98^{\mathrm{b}} \pm 0.00$ & $3.85^{\mathrm{c}} \pm 0.01$ \\
\hline 120 & $2.99^{\mathrm{b}} \pm 0.01$ & $2.00^{\mathrm{a}} \pm 0.00$ & $7.98^{\mathrm{c}} \pm 0.01$ & $3.00^{\mathrm{b}} \pm 0.00$ \\
\hline
\end{tabular}

Table 8: Reducing sugar produced by Manihot esculenta peels hydrolysates.

Key: Control is the sample without pretreatment.

Neutral is the sample acidified with $\mathrm{H}_{2} \mathrm{SO}_{4}$ and neutralized with $\mathrm{NaOH}$.

Figure 1 showed the $\mathrm{pH}$ of Manihot esculenta peels during the production of bioethanol. In this study, the $\mathrm{pH}$ was varied between 4.44 to 7.67 and the results obtained as presented indicate that the bioethanol yield increases with increase in $\mathrm{pH}$. The highest $\mathrm{pH}$ of 7.67 was observed in day 1 in neutralized pretreated cassava peels while the lowest $\mathrm{pH}$ of 4.44 was observed in day 2 in pretreated $\mathrm{NaOH}$ sample. This result closely agrees with the results reported by Muhammad., et al. [32] and Akpan., et al. [33] who reported the highest $\mathrm{pH}$ of 5 and 5.12 respectively.

The result in figure 2 revealed that the temperature of the fermented Manihot esculenta peels. During the period of fermentation, the temperature of Manihot esculenta peels pretreated with

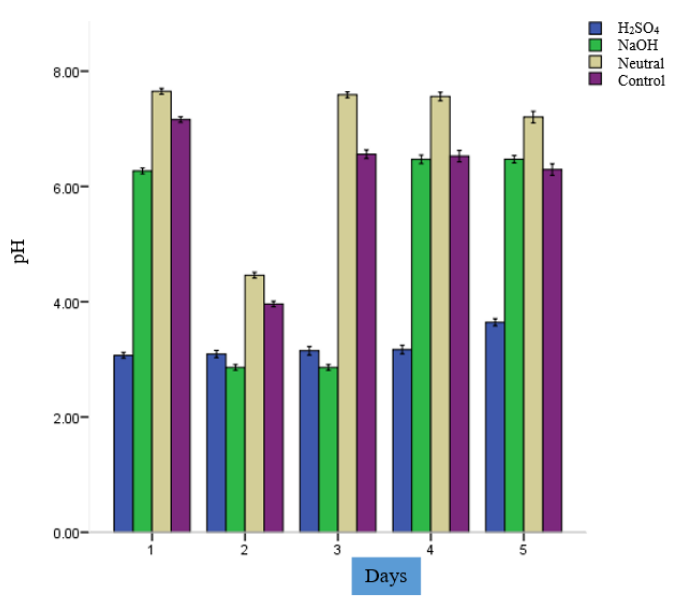

Figure 1: pH of Manihot esculenta during fermentation.

$\mathrm{H}_{2} \mathrm{SO}_{4}, \mathrm{NaOH}$, neutralized $\left(\mathrm{H}_{2} \mathrm{SO}_{4}\right.$ neutralized with $\left.\mathrm{NaOH}\right)$ and control was at $36^{\circ} \mathrm{C}$ at the initial stage and remain static at $28^{\circ} \mathrm{C}$ daily till 120 hours respectively. The static temperature as observed in the hydrolysates in the course of fermentation of the peels could be due to the ambient temperature of the experimental environment as well as the temperature of the fermentation vessels. The outcome of the findings in this study is in contrast of the observation of Bagus and Bondan [34], Brooks, [35], Kadambini and Anoop, 
[36], Michelle., et al. [37], Mohammed., et al. [38] and Oyeleke., et al. [39] who observed that temperature of $30-37^{\circ} \mathrm{C}$ is the optimum temperature used for the production of bioethanol from Manihot esculenta peels.

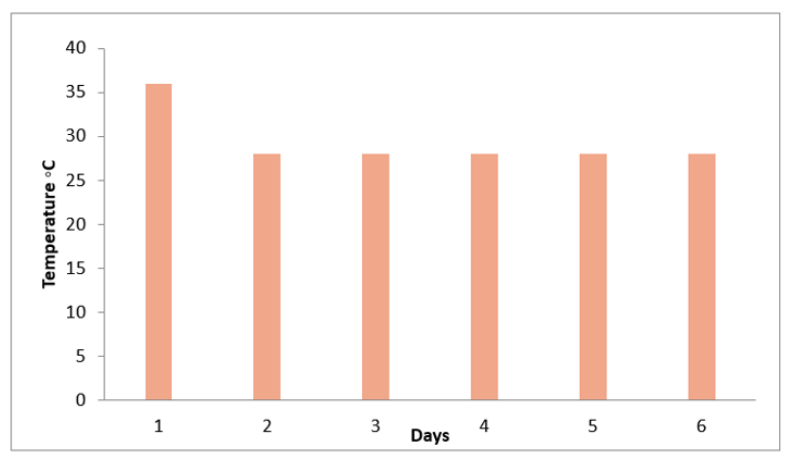

Figure 2: Temperature of Manihot esculenta during fermentation.

Findings from figure 3 showed that high bioethanol content were produced from Manihot esculenta peels by the pretreatment of $\mathrm{H}_{2} \mathrm{SO}_{4}$ at $17.08 \mathrm{~g} / \mathrm{ml}$. Thus, $\mathrm{H}_{2} \mathrm{SO}_{4}$ is a potent oxidizing agent and also improve enzymatic hydrolysis for the production of bioethanol. This is supported by the research carried out by Ouyang., et al. [40] who developed two step pretreatment of Chinese fir sawdust using dilute sulphuric acid. Under optimal condition, they quantified $76.8 \%$ yield of bioethanol which depict the efficacy of sulphuric acid.

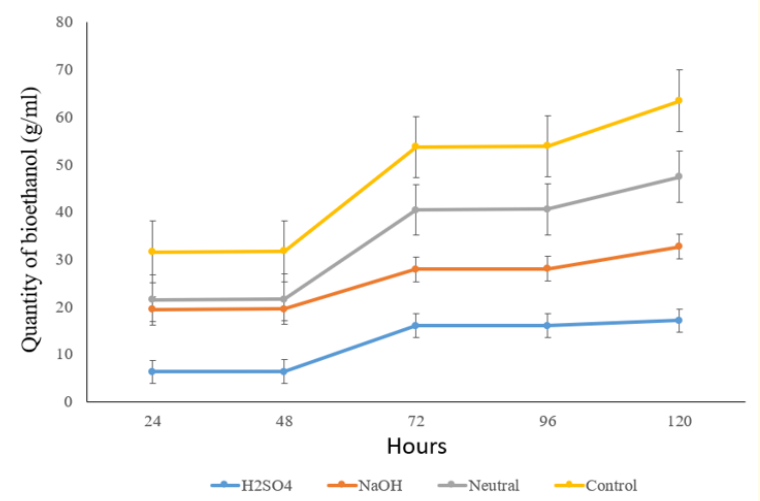

Figure 3: Quantity of bioethanol contents produced from Manihot esculenta peels.

\section{Conclusion}

This study established that bioethanol can be produced from Manihot esculenta peels and this serves as cheap alternative source of biofuel and bioenergy generation. Bioethanol was successfully produced from Manihot esculenta peels through simultaneous saccharification and fermentation of their hydrolysates with Aspergillus niger and Zymomonas mobilis in 120 hours fermentation period. From the results gotten it can be resolved that the $0.1 \mathrm{M}$ of $\mathrm{H}_{2} \mathrm{SO}_{4}$ is the most effective concentrations for pretreating the peels of cassava.

\section{Bibliography}

1. Balat M. "Recent trends in global production and utilization of bioethanol fuel". Applied Energy 86.11 (2009): 2273-2282.

2. Banjoko OS., et al. "Nutritional Evaluation of Layers Diets based on cassava products and soya beans as influenced by protein supplementation and processing". Proc. 33rd Annual Conf. of NSAP, Ayetoro, Ogun State Nigeria (2008): 373-376.

3. Lebot V. Tropical Root and Tuber Crops: Cassava, Sweet Potato, Yams and Aroids. CABI, Cambridge, MA., USA (2009): 433.

4. Adebayo K and Sangosina M A. "Processors' Perception of the Effectiveness of some Cassava Processing Innovations in Ogun State, Nigeria" (2005).

5. Adebayo K., et al. "Perception of Environmental Issues by Cassava Processors in Ogun State, Nigeria - Implications for Environmental Extension Education". Journal of Extension Systems 19 (2003): 103-112.

6. Agwu A E and Anyaeche C L. "Adoption of improved cassava varieties in six rural communities in Anambra State, Nigeria". African Journal of Biotechnology 6.2 (2007): 089-098.

7. Adebayo G J., et al. "Evaluation of yield of oyster mushroom (Pleurotus pulmonarius) grown on cotton waste and cassava peel”. African Journal of Biotechnology 8.2 (2009): 215-218.

8. Onuoha C I., et al. "Cultivation of Pleurotus pulmonarius (mushroom) using some agro-waste materials". Agricultural Journal 4.2 (2009): 109-112.

9. Adelekan BA. "Recent Advances in Renewable Energy: Research, Applications and Policy Initiatives". Physical Review and Research International 2.1 (2012): 1-21. 
10. Kortei N K., et al. "Assessing the effect of composting cassava peel based substrates on the yield, nutritional quality, and physical characteristics of Pleurotus ostreatus (Jacq. Ex fr.) Kummer". Biotechnology Research International (2014): 1-10.

11. Ovueni UJ., et al. "Effect of Acid and Alkali Pretreatments on the Structural and Compositional Properties of Cassava Peels". International Journal of Scientific and Engineering Research 11.5 (2020): 116.

12. Kumar AK and Sharma S. "Recent updates on different methods of pretreatment of lignocellulosic feedstocks: a review". Bioresource Bioprocess 4.1 (2017): 7-9.

13. Hemraj V., et al. "A review of commonly used biochemical test for bacteria". Innovare Journal of Life Sciences 1.1 (2013): 1-7.

14. Fawole MO and Oso BA. "Laboratory manual of microbiology". Spectrum Books Limited, Ibadan, Nigeria (2010).

15. Saha BC and Cotta MA. "Ethanol production from alkaline peroxide pretreated enzymatically saccharified wheat straw". Biotechnology Proceedings 22 (2006): 449-453.

16. Kroumov AD., et al. "Development of new unstructured model for simultaneous saccharification and fermentation of starch to ethanol by recombinant strain". Journal of Biochemical Engineering 28 (2006): 243-255.

17. Oyeleke SB., et al. "Production of bioethanol from cassava and sweet potato peels". Advanced Environmental Biology 6.1 (2012): 241.

18. Ademiluyi FT and Mepba HD. "Yield and properties of Ethanol Biofuel produced from Different Whole Cassava Flours" (2013).

19. Humphrey $\mathrm{CN}$ and Okafoagu UC. "Optimization of ethanol production from Garcinia kola (bitter kola) pulp agro waste”. African Journal of Biotechnology 6.17 (2007): 2033-2037.

20. Srichuwong S and Jane JL. "Methods for characterization of residual starch in distiller's dried grains with solubles (DDGS)". Cereal Chemistry 88.3 (2011): 278-282.

21. Ayansina ADV., et al. "Characterization of amylase from some Aspergillus and Bacillus species associated with cassava waste peels". Advances in Microbiology 7.4 (2017): 280.
22. Linden PK., et al. "Invasive aspergillosis in liver transplant recipients: outcome comparison of therapy with amphotericin B lipid complex and a historical cohort treated with conventional amphotericin". Journal of Clinical and Infectious Diseases (2003): 17-25.

23. Giray B., et al. "Aflatoxin levels in wheat samples consumed in some regions of Turkey". Food Control 18 (2007): 23-29.

24. Reddy KRN., et al. "Aflatoxin B1 producing potential of Aspergillus flavus strains isolated from stored rice grains". African Journal of Biotechnology 8 (2009): 3303-3308.

25. Rabah AB., et al. "Dilute acid pretreatment of millet and guinea corn husks for bioethanol production". International Journal of Microbiology 2.11 (2011): 460-465.

26. Okpako CE., et al. "Proximate composition and cyanide content of cassava peels fermented with Aspergillus niger and Lactobacillus rhamnosus". Journal of Food Agricultural Environment 6 (2008): 251-255.

27. Adamafio NA., et al. "Potash pretreatment enhances carbohydrate biodegradability and feed potential of groundnut (Arachis hypogea) shell meal". Journal of Applied Sciences 12 (2012): 1408-1412.

28. Charles AL., et al. "Proximate composition, mineral contents, hydrogen cyanide and phytic acid of 5 cassava genotypes". Food Chemistry 92 (2005): 615-620.

29. Onyelucheya OE., et al. "Acid Hydrolysis of Cassava Peel". International Journal of Scientific and Technology Research 5.1 (2005): 184-188.

30. Aripin AM., et al. "Cassava peels for alternative fibre in pulp and paper industry: chemical properties and morphology characterization". International Journal of Integrated Engineering 5.1 (2013).

31. Yooan K and Kongkiattikajorn J. "A study of optimal conditions for reducing sugars production from cassava peels by diluted acid and enzymes". Agriculture and Natural Resources 38.5 (2004): 29-35.

32. Mohammed D., et al. "Optimum hydrolysis-fermentation parameters for the production of bioethanol from the Nigerian 
stem juice of sweet sorghum". Petroleum Technology Development Journal 7.1 (2011): 64-73.

33. Akpan U G., et al. "Production of ethanol fuel from organic and food wastes". Leonardo Electronic Journal of Practices and Technologies 18.12 (2008): 1-11.

34. Bagus W M and Bondan A C. "Production of bioethanol from cassava peels waste by using sweet corn enzyme powder". Indonesia: Semarang Press (2008).

35. Brooks A A. "Ethanol production potential of local yeast strains isolated from ripe banana peels". African Journal of Biotechnology 7.20 (2008): 3749-3752.

36. Kadambini G and Anoop V. "Process optimization for the production of ethanol via Fermentation". Thapar Institute of Engineering and Technology (Deemed University). Patiala, Thailand: University Press (2006).

37. Michelle L M., et al. "Factors affecting ethanol fermentation via simultaneous saccharification and fermentation: A study to determine the optimal operating conditions to convert cellulosic biomass into ethanol during enzymatic hydrolysis and microbial fermentation". Worcester Polytechnic Institute (2011).

38. Oyeleke S B., et al. "Production of bioethanol from cassava and sweet potato peels". Journal of Advances in Environmental Biology 5.12 (2011): 3729-3733.

39. Ouyang S., et al. "Development of two-step pretreatment of Chinese fir sawdust using dilute sulphuric acid followed by sodium chlorite for bioethanol production". Cellulose 26.15 (2019): 8513-8524.

Volume 4 Issue 11 November 2021

(C) All rights are reserved by Deke Victoria Adegunloye and Janet Olawumi Olowe. 